\title{
AGATLHY JUNG E HILDA ABRAHAM: PRIMEIRAS EXPERIÊNCIAS DE PSICANÁLISE COM CRIANÇAS ${ }^{1}$
}

\author{
Adela Stoppel de Gueller; AnA Costa
}

Adela Stoppel de Gueller

Universidade do Estado do Rio de Janeiro (UERJ), PósDoutora pelo Programa de PósGraduação em Psicanálise, Rio de Janeiro/RJ, Brasil.

Ana Costa Universidade do Estado do Rio de Janeiro (UERJ),

Professora do Programa de PósGraduação em Psicanálise, Rio de Janeiro/RJ, Brasil.
RESUMO: Além de ser uma das cinco grandes psicanálises de Freud, o pequeno Hans é o primeiro paciente da psicanálise com crianças. Outras experiências semelhantes estão em série com esse caso; foram feitas na sequência, mas ficaram esquecidas pela história. Discutimos aqui duas delas: o caso Ana/Agathly (Jung, 1910) e o caso Hilda (Abraham, 1913). Como Hans, elas estiveram em tratamento psicanalítico conduzido por seus respectivos pais. Os casos dão subsídios importantes para pensar as teorias sexuais infantis elaboradas por meninas.

Palavaras-chave: psicanálise com crianças; escritas da clínica; história da psicanálise; Abraham e Jung; teorias sexuais infantis.

ABSTRACT: Agatlhy Jung and Hilda Abraham: first experiences in child psychoanalysis. Besides being one of the Freud's big five psychoanalysis clinical case studies, Little Hans is the first child psychoanalysis patient. In series with this case, following similar experiences were made but lay forgotten by history. In this paper we discussed two of this experiences: the Ana/Agatlhy (Jung, 1910) and the Hilda (Abraham, 1913) clinical case studies. As Hans, they have been in psychoanalytical treatments conducted by their respective fathers. The cases imply substantial contributions to thinking about the sexual theories of children elaborated by little girls.

Keywords: child psychoanalysis; clinical writings; history of Psychoanalysis; Abraham and Jung; sexual theories of children.

DOI - http://dx.doi.org/10.1590/1809-44142017003006 


\section{ESCRITAS DO CASO CLÍNICO}

A escrita de caso é um lugar importante na transmissão da psicanálise. Ela tem tido a função de nomear a "outra cena" como algo que resta do fantasma construído em transferência. A psicanálise não se pauta pela naturalização de um desenvolvimento, mas lida com construções que operam o sítio do corpo no espaço, nas relações amorosas e nos circuitos pulsionais. O recorte da "outra cena", que sustenta a relação do sujeito ao Outro, é constituído por alguns significantes e movimentos pulsionais que se decantam na transferência. É do que resta de enigmático nesse movimento que se constrói a escrita do caso, naquilo que desse enigma estimula a produção do analista.

Desde Freud, testemunhamos que essa escrita não transmite um modelo de como fazer no acompanhamento das análises, mas busca passar elementos que restam sem resolução. Trabalhando com os casos escritos por Freud, Lacan se perguntava tanto sobre o desejo do autor quanto sobre um engajamento fantasmático. Ou seja, colocava sua pergunta na direção do desejo do analista. De qualquer forma, pode-se reconhecer quando uma escrita se engaja numa questão fantasmática ou quando se pauta pelo desejo do analista. Encontramos essa diferença não somente na escrita do caso. Importa situar essa questão no tema que nos leva a produzir este texto. Assim, ao pensar na transmissão da psicanálise, nos indagamos quais efeitos se dão quando determinadas produções são recalcadas na história do movimento psicanalítico. Esta pergunta diz respeito às escritas de caso, operadas pelos analistas/pais, anteriores ao reconhecimento de uma clínica com crianças.

\section{EM TORNO DO BERÇO}

Vinte anos depois da publicação do caso Hans, nasceu oficialmente a psicanálise com crianças, em 1926/27. Nesse momento, Anna Freud e Melanie Klein instauram-se como suas duas grandes mães e se enfrentam numa longa querela litigiosa; como na proverbial história do Rei Salomão, disputam a propriedade da criança.

A psicanálise com crianças tem então um nascimento em dois tempos. Hans, Agathly, Hilda, Arpad e vários outros casos ficaram situados como a pré-história da psicanalise com crianças. Só Hans sobreviveu como vestígio dessa época. Os outros casos ficaram sepultados e só começaram a ser desenterrados a partir dos anos 1970.

O caso Hans foi publicado em $1909 .{ }^{1}$ O pai do menino, Max Graf, era um dos psicanalistas mais próximos de Freud e começou a descrever os diálogos que tinha com seu filho, atendendo a um pedido do próprio Freud ${ }^{2}$, que pretendia confirmar in status nascendi as hipóteses do artigo Três ensaios sobre uma teoria sexual (1905). Mas, no decorrer dessa observação, o menino manifestou um sintoma fóbico - o medo de cavalos -, e Max pediu a Freud orientações para tratá-lo psicanaliticamente.

Em seguida, foram escritos outros dois casos dessa série inicial, que ficaram esquecidos. Tratam-se de duas meninas, e ambos os percursos são semelhantes ao de Hans: as observações se converteram em tratamento quando surgiram sintomas. Assim como aconteceu com Hans, o tratamento foi conduzido por seu pai. No caso Agatlhy, essa relação está dissimulada, como o fez Melanie Klein ao descrever o tratamento de seu filho Erich/Fritz em The development of a child, apresentado em 1919 e publicado em 1921 (KLEIN, 1921/1964, p. 19).

Foi só em 1920, no Congresso Internacional da Haia, que Hermine Hug-Hellmuth criticou esse procedimento. Contestou a afirmação de Freud de que seria bom que o pai e o analista fossem a mesma pessoa, com o argumento de que os filhos jamais revelam seus desejos e pensamentos mais íntimos a seus pais. Nesse quesito, Hermine questionou explicitamente o que Freud tinha afirmado no caso Hans, sobre a junção da autoridade e da confiança que o pai teria sobre a criança, condição da transferência na infância, e também a análise que sua filha Anna Freud tinha acabado de fazer com ele.

\section{O CASO DE AgATHLY}

Em 1910, Jung publicou o caso Agathly, a quem denominou Aninha ${ }^{3}$. Esta, segundo suas palavras, mostrou “tão notáveis analogias com as [observações] de Freud e as completava tão admiravelmente, que não pude resistir ao

\footnotetext{
${ }^{1}$ Embora Freud tenha escrito outros dois textos que falam dele: $O$ esclarecimento sexual da criança (carta aberta ao Dr. M. Fürst) e As teorias sexuais infantis, respectivamente em 1907 e em 1908.

${ }^{2} \mathrm{Na}$ introdução a O pequeno Hans, Freud escreve: “Por muitos anos, tenho insistido com meus pupilos e com meus amigos a coletar observações sobre a vida sexual das crianças - cuja existência, via de regra, tem sido ignorada ou deliberadamente desmentida" (FREUD, 1909, p. 8).

${ }^{3}$ Optamos aqui por chamá-la Agatlhy, para levantar o véu que recaiu sobre o laço entre pai e filha, recoberto pelo nome fictício Aninha.
} 
desejo de dá-las a conhecer" (JUNG, 1913/1964). Foi apresentado como uma conferência em 1909, na Clark University, por ocasião da comemoração de seus 20 anos, com a presença de Freud. ${ }^{4}$ Ele ministrou as Cinco conferências sobre psicanálise, e Jung fez três palestras; na terceira, falou sobre essa análise. Freud mencionou o caso uma única vez, na quarta conferência, de 1909: “Devo lembrar-Ihes que meu amigo Dr. C. G. Jung, há poucas horas, nesta mesma sala, lhes expôs a observação de uma menina ainda mais nova, que, pelo mesmo motivo do meu paciente (o nascimento de um irmãozinho), ${ }^{5}$ evidenciava quase os mesmos impulsos sensuais e idêntica formação de desejos e complexos" (FREUD, 1910/1996, p. 39).

Jung expõe o caso seguindo o mesmo método clínico que Freud no caso Hans: inicialmente, conta cenas isoladas, depois se detém no surgimento da fobia e em sua resolução, e então encerra com considerações.

Aos 4 anos, Agathly estava em plena elaboração das teorias sexuais infantis. Ela também fez uma fobia, mas tratava-se do medo de terremotos. Sabemos hoje que, nesse momento, o casal estava abalado, em função do relacionamento de Jung com Sabina Spielrein, e é possível pensar, como afirmou Renata Cronberg, ${ }^{6}$ que, com seu sintoma, Agathly tenha sido uma analisadora da sexualidade dos pais.

Às vésperas do nascimento do seu irmãozinho Fritz, Agathly se perguntava como se faria lugar para mais um, como se criaria um lugar novo. Isso é possível ou é necessário liberar um que já existe e está ocupado? Então, perguntou à avó se ela iria morrer e se no lugar dela viria o irmão. Agathly estava construindo uma teoria sobre a reencarnação que seguia o lema "nada se perde, tudo se transforma" e, assim, pretendia resolver o enigma da criação (nascimento) e da desaparição (morte).

Quando Fritz nasceu, Agathly perguntou à mãe: "Vou ser uma mulher diferente de você?". E, referindo-se à cegonha, perguntou ainda: "É verdade que você não mente?". Nesse momento, ela também começou a brincar de ser como a ama que amamentava o irmão. Até aí, tudo ia bem com Agathly, mas, pouco depois, a angústia eclode, e ela começa a acordar à noite chorando. Coincidentemente, ouve falar de um terremoto em Messina que causara muitas mortes, ${ }^{7}$ e suas perguntas passam a se fixar nos terremotos. Agathly muda repentinamente quando suspeita que sua mãe mente, questão fundamental, o que faz com que a menina perca estabilidade e segurança.

Inicialmente, Agathly pede à avó que lhe conte mais: "Como tinha tremido a terra? Como tinham caído as casas? Como milhares de pessoas tinham morrido soterradas?". E ela começa a ter medo de ficar sozinha. Se a mãe não ficava ao lado de sua cama, à noite, dizia que "o terremoto virá e a casa cairá, matando-a" (JUNG, 1913/1964, p. 21). Quando saía de casa, perguntava: "A casa vai estar inteira quando voltarmos? Papai ainda vai estar vivo? Tem certeza de que lá em casa não tem terremoto?". Agathly acordava gritando: "O terremoto está chegando! Ouço o rugido dele!". Esse curioso substantivo dá uma pista para pensar que o terremoto é como um leão, logo, ele poderia ser um substituto da figura paterna, se supusermos uma operação semelhante à que Freud inferiu sobre o cavalo de Hans. Assim como o cavalo, o terremoto é uma figura ameaçadora, temida. Mas o traço que Agathly extrai dessa figura é o rugido, que remete à voz do pai. Não é uma boca que morde e pode arrancar uma parte preciosa do corpo, mas um rugido que a faz perder o chão. Jung não faz essa inferência, e foi por isso criticado por Freud.

Em sua correspondência com Jung, após a publicação, Freud elogia o caso Agathly, mas indica a falta de uma análise comparativa com o caso Hans: "Reli com prazer a fascinante história das crianças (Agathly e Sofia), lamentando, entretanto, que o pesquisador não dominasse o pai por completo; ela é de fato um relevo frágil, quando poderia ter sido vigorosa estátua, e, devido a tal sutileza, a lição se perde para a maioria dos leitores. [...] Pena que as analogias com o pequeno Hans não sejam devidamente trabalhadas, senão aqui e ali, pois o leitor é, por definição, um simplório, e é preciso que lhe esfreguemos as coisas no nariz" (FREUD, 2012, p. 362, grifo nosso). ${ }^{8}$ Ali, Freud mostrou claramente o quanto a questão do pai estava no centro de suas preocupações, questão que seria retomada na releitura que ele mesmo fez de Hans em Tótem y Tabu (1913/1996). Mostrou ainda o quanto o irritava que seus

${ }^{4}$ Freud e Jung foram convidados por Stanley Hall - então reitor - para celebrar os 20 anos da Clark University, em Massachusetts. Por insistência de Jung, Hall chamou Freud para substituir Wundt, que declinara do convite. A conferência foi publicada inicialmente em Jarbuch für psychoanalytische und psychopathologische Forschungen II (Anuário de Pesquisas Psicanalíticas e Psicopatológicas II, Viena e Leipzig, 1910, p. 33-58).

${ }^{5} \mathrm{O}$ verdadeiro nome de seu irmãozinho - Franzli, no texto - era Fritz.

${ }^{6}$ No Colóquio 100 anos de Psicanálise com Crianças, realizado nos dias 28 e 29 de agosto de 2009 no Instituto Sedes Sapientiae, em São Paulo.

${ }^{7}$ Em 28 de dezembro de 1908, houve na Itália um terremoto que destruiu a cidade de Messina, deixando 75 mil mortos.

${ }^{8}$ Em carta de 18 de agosto de 1910. 
discípulos e amigos não o acompanhassem nesse ponto que, para ele, constituía o complexo nuclear das neuroses. ${ }^{9}$ No entanto, não podemos deixar de considerar que o terremoto surgiu quando Agatlhy perdeu a confiança na palavra materna, que garantia "a estabilidade da terra e do mundo em geral" (WINNICOTT, 1947/1965). É a mãe que cai do lugar Ideal e torna-se real, ao perder o lugar de fiadora da palavra, deixando a criança no mais absoluto desamparo. Eis mais um ponto de convergência com o caso Hans.

Sem a garantia do Outro, tudo treme, e Agathly subitamente acorda do mundo dos sonhos. De que despertar se trata? As fobias, diz Freud, são as neuroses típicas da infância porque permitem encontrar uma solução em momentos de passagem, de incerteza, em momentos de crise subjetiva; e o Édipo constitui o modelo e o protótipo dessas situações. Elas surgem frente ao que é incerto, ambíguo, como a própria infância - por isso, estrutura indecidida. A fobia permite reestruturar o espaço ali onde se havia formado um beco sem saída, delimitando ao menos um lugar onde não se deve entrar ou do qual é melhor ficar longe. Em tempos do Édipo, isto é, quando a criança ainda não decidiu se prefere ficar do lado do pai ou da mãe e se interroga sobre a diferença entre eles, quando não sabe que lugar lhe vai restar porque vem um irmão, uma fobia não chega a ser uma luz no fim do túnel, mas é ao menos uma placa que indica que ali é melhor não transitar e, disso, o sujeito tem certeza.

Os pais de Agathly não entendiam o que se passava com ela. Por que esse temor repentino? Só tiveram uma pista quando ela começou a perguntar por que a irmã, Sofia, era mais nova que ela. Onde estava Fritz antes de nascer; no céu? O que fazia ali, por que descera agora e não antes? O pai decide então que é uma boa hora para esclarecimentos, e pede que a mãe lhe explique a verdade sobre a origem do irmãozinho. Na primeira oportunidade que teve, a mãe lhe explicou que a história da cegonha não era verdade, que o irmão tinha se formado no corpo dela, do mesmo modo que as flores nascem na terra. Agathly indicou o peito da mãe e perguntou: "Será que aí existe algum buraco ou será que ele saiu pela boca? E a ama, o que saiu dela?" Nesse mesmo momento, começou a gritar: "Sei muito bem que a cegonha trouxe meu irmão do céu". E, em seguida, sem mais explicações, pediu para ver um atlas com desenhos e gravuras da biblioteca do pai, com imagens de vulcões e terremotos, que a mãe lhe havia dado (JUNG, 1913/1964, p. 22).

Jung comentou que Agathly já tinha sido proibida de se masturbar e que era esse o motivo pelo qual ela perguntava sobre os buracos superiores (seio e boca) e ignorou os inferiores (vagina e ânus), deduzindo disso um primeiro efeito da operação de recalque. Vemos a curiosidade sexual em plena erupção e a busca pelo conhecimento como um bálsamo que poderia acalmá-la. As perguntas de Agathly giram em torno do que está dentro do corpo materno e das portas de saída desse interior, mas lhe interessa particularmente entender o que fica no lugar disso que sai. É por aí que suas perguntas a conduzem ao não-ser, à não-existência. E a mera possibilidade de se aproximar disso lhe causa horror, ao confrontá-la com a ideia de vazio. Onde estavam os bebês antes de nascer? Se algo sai pela boca, pelo buraco do peito ou da barriga, o que fica nesse lugar?

O comentário de Jung sobre a proibição da atividade masturbatória de Agathly induz a pensar que, além do corpo materno, o terremoto articula também, numa única representação, lei e gozo (o rugido/voz do pai e a lava quente que vem do corpo, as pulsões). Mas de que dimensão do pai se trata? Não é o pai que porta a palavra articulada, mas um barulho que atemoriza e que se apresenta clinicamente como supereu. Eis a dimensão que Lacan situou como além do Édipo. ${ }^{10}$ Trata-se de um pai que se apresenta como excessivo e que não pode ser recoberto pelo campo do amor. Não é então o pai edipiano, o pai amado/odiado, mas justamente aquilo que não entra no registro amoroso que unifica, mas permanece como traço (LACAN, 1992, p. 10-11).

\section{RESOLUÇÃO DA FOBIA DE TERREMOTOS}

Agathly encontrou uma solução para a fobia muito mais depressa que Hans. No lugar do encanador, ela e sua irmã inventaram um irmão imaginário mais velho, que sabia tudo e podia tudo, dono de animais. Esse irmão, diz Jung, é o pai, que é como se fosse um irmão da mãe, ou seja, um tio, do que nós inferimos: uma versão masculina da mãe onipotente ou, nos termos de Lacan, o pai imaginário que protege. Agathly faz a ele um apelo para aplacar sua angústia: "Meu irmão está na Itália. Ele tem uma casa de vidro e de estufa que não vai tombar". Se mamãe disse que as crianças crescem como as plantas, podemos pensar que uma estufa - ou seja, um lugar onde se fazem crescer

\footnotetext{
${ }^{9}$ Vale lembrar também que, no primeiro texto em que fala da Urphantasien (1915/1996), Freud destacou o barulho que aciona a fantasia da criança que está com o ouvido à espreita e que forma parte do complexo parental. É o barulho que acorda a criança, mas também o barulho que ela teme fazer, que trairia sua presença na cena primitiva.

${ }^{10}$ Aí, além não remete ao que vem depois, mas tem o mesmo sentido que Freud lhe deu em Além do princípio do prazer, de 1920.
} 
plantas - bem pode representar a barriga da mamãe. Aliás, em português, as grávidas dizem que se sentem estufadas, infladas. ${ }^{11}$ Lembremos também quão frequentemente as crianças colocam almofadas na barriga para simular que estão grávidas. Curiosamente, étoffe também significa liga de estanho com ferro, material estrutural com que se fazem canos. Assim, podemos imaginar uma estufa feita de canos e vidro, resultando numa estrutura forte e ao mesmo tempo transparente, que permite ver o que se passa no interior do corpo materno, especialmente na barriga. ${ }^{12}$ A Itália é o país do terremoto, o lugar onde as casas desabaram. Mas a construção que as irmãs imaginam como solução (a estufa) é uma casa de cano e vidro que possibilita ver e está protegida.

O grande irmão imaginário, poderoso e possuidor de animais (as pulsões), faz desaparecerem o medo de terremotos e o interesse por eles. Curiosamente, Agatlhy transforma o pequeno intruso num irmão grande que a protege, e isso faz com que a angústia diminua. Se o irmão é mais velho, ela não precisa ceder seu lugar. Ela passa então a demonstrar ternura pelo pai, indicando que o terremoto poderia ser um substituto do pai imaginário terrorífico e pergunta se o pai tinha nascido da avó e se ela e a irmã também tinham estado na barriga da mãe. No dia seguinte, Jung fica de cama. Entre espantada e tímida, Agathly indagou: "Por que você está na cama? Você também tem uma planta na barriga?". O pai riu e tranquilizou-a; disse que nenhuma criança podia se formar no seu corpo, que os homens jamais tinham filhos, só as mulheres. Agathly saiu do quarto alegre e despreocupada. É interessante notar que o temor reside em que possa não haver diferença sexual entre o pai e a mãe. Ela está buscando o que marca a diferença dos sexos, tentando diferenciar o pai da mãe, e suspeita que seu pai tem algum papel na procriação. $O$ irmão imaginário aparece então como um representante fálico, permitindo que se esboce a diferença sexual. Mas insiste na pergunta: o pai também guarda coisas na barriga? Será que o pai não guarda nada ali?

Dias depois, Agathly contou para a avó que tinha sonhado com a arca de Noé e que dentro dela havia muitos animaizinhos. ${ }^{13} \mathrm{Um}$ pouco mais tarde, recontou o sonho assim: "Sonhei com a arca de Noé; havia muitos animaizinhos lá dentro e, embaixo, havia uma tampa que se abria e todos os animaizinhos caíam". ${ }^{14}$ O sonho parece levantar o recalque, permitindo que apareçam os buracos inferiores. Mas também mostra a junção dos animais, a excitação que a masturbação causa e a questão sobre a origem dos bebês. Ou seja, no sonho, ela se interroga sobre o interior de seu corpo: dele também podem sair bebês? Os animais habitam seu corpo, saem pelo buracos inferiores, caem. $\mathrm{O}$ irmão imaginário os dominava - ela não tinha esse poder.

\section{DO VER AO FAZER}

Alguns dias depois, a angústia retorna. Agathly acorda com um pesadelo: “O terremoto vem vindo. A casa está se mexendo!". A mãe acode para tranquilizá-la, e ela diz: "Gostaria tanto de ver a primavera e como crescem as florzinhas! Gostaria de ver o prado todo florido e também Fritz, que tem uma cara tão bonitinha! E papai, o que ele está dizendo, o que está fazendo?". Mãe: "Nada. Está dormindo". Agathly, zombeteira: "Acho que amanhã vai cair de cama de novo".

Na manhã seguinte, Agathly não se lembrava do pesadelo, mas disse que tinha tido um sonho: "Sonhei que eu podia fazer o verão, depois alguém jogou um polichinelo na privada". Ela agora podia fazer o verão, ou seja, ela também podia fazer um bebê. Essa teoria parece bem semelhante à do excremento de Hans: a criança é tida como um equivalente do cocô e sai do mesmo jeito. Mudaram as estações, como diz Renato Russo, mas nada mudou? A elaboração onírica parece ter possibilitado que Agathly avançasse na sua pesquisa teórica: na primavera, ela queria ver e saber, mas surge a incerteza e o pai terremoto retorna. No verão, sua posição é outra: ela pode fazer e ter um bebê. A nova equivalência simbólica é entre o bebê e o cocô. Mas também mudou sua posição subjetiva - agora, ela é ativa e produtiva.

Um dia, ela vai correndo à cama dos pais, deita-se de bruços, dá uns coices e diz: "Não é verdade que o papai faz assim?". Os pais riem, mas não respondem. Jung lembra-se do cavalo de Hans. Agathly supõe que o pai faz algo

\footnotetext{
${ }^{11}$ De verre e d'étoffé, lemos na vesão francesa. A tradução ao português diz "de vidro e pano", o que nos levara a pensar que se tratava de uma cabana/vitrine frágil. Mas parece-nos que outro dos sentidos da palavra étoffe (estufa) é muito mais próximo do raciocínio de Agathly. $O$ importante aqui é que se trata de materiais que dão estrutura, suporte, como a estrutura de um chapéu ou o recheio de uma almofada.

${ }^{12}$ A palavra estupa, da mesma origem, provém do sânscrito e originariamente fazia referência aos túmulos funerários que se construíam na Índia antiga sobre as relíquias de importantes personagens religiosos como o Buda.

13 Lembremos que o irmão mais velho era dono de muitos animais.

${ }^{14} \mathrm{~A}$ menina tinha uma arca de Noé de brinquedo cuja tampa se abria na parte superior.
} 
com as pernas, mas ainda não sabe exatamente o quê. Ou seja, começa a pensar que o homem tem um papel diferente na reprodução.

Cinco meses depois, surge um novo temor. Nas férias, Agathly está com medo de mergulhar. O pai a provoca e a afunda na água. Ela então diz: “Não é verdade que papai quis me afogar?”. Nesse episódio, Freud viu um mascaramento do parto ${ }^{15}$ (FREUD, 2012, p. 362) ${ }^{16}$ e, seguindo essa interpretação, ela estaria identificada com o bebê.

Uns dias depois, Agathly provoca o jardineiro, que acaba jogando-a numa valeta. Ela grita, desesperada, e diz que o jardineiro quis soterrá-la, ou seja, teme ficar como as pessoas que morreram no terremoto. (Lembremos que, na metáfora dada pela mãe, o bebê se forma como as flores que nascem na terra.) Novamente, nascimento e morte se sobrepõem: ela também poderia ser uma semente/bebê. Se a teoria da reencarnação continua vigente e ela ainda pensa que ninguém pode passar a existir se alguém não desaparece, qual seria a consequência de Fritz estar ali? Será que é ela - e não a avó - que pode morrer? A disjuntiva parece ser "ou ele, ou eu", o que explica por que o nascimento do irmão provocou tamanha comoção na menina e também por que a substituição de um bebê por um irmão mais velho a acalmou.

Em seguida, Agathly e Sofia inventaram uma brincadeira que irritou a mãe: transformaram um canto do jardim em casa de brinquedo e começaram a fazer ali suas necessidades. A mãe interveio proibindo-as, e Agathly: “Quando a mamãe morrer, poderemos fazer todos os dias ali e pôr nossos vestidos de domingo". A identificação com a mãe parece já ter-se constituído. Agathly não precisa mais da mãe, pode se livrar dela, que não a deixa fazer à vontade. Pode também salvar a própria pele: basta se livrar da mãe.

Outro dia, ela brincou com o jardineiro de arar a terra e, quinze dias depois, viu a grama nascendo e perguntou à mãe: "Os olhos foram plantados na cabeça?". A mãe respondeu: "Não sei”. Agathly: "E Deus sabe? E papai? Por que Deus e papai sabem tudo?". A mãe aconselhou a filha a levar a pergunta ao pai, e Agathly seguiu a indicação: "Como é que os olhos foram para dentro da cabeça?". Jung respondeu "Não, eles estavam ali desde o início". Agathly: "Não foram plantados dentro?". Pai: "Não, eles só cresceram e fazem parte da cabeça, como o nariz também”. Agathly: "E a boca e as orelhas e os cabelos também?". Pai: "Sim”. Agathly: "E os cabelos também? Mas os ratos não nascem sem pelos? Onde ficam os pelos antes que a gente os veja? Não tem que pôr sementinhas antes?". Pai: "Não, os pelos saem de grãozinhos que já estão antes na pele, e ninguém os semeou". As respostas de Jung não lhe permitem avançar na teorização. O corpo a que ela se refere é o do desejo, não o da biologia. As perguntas de Agathly parecem ser pelas partes do corpo, principalmente pelos objetos parciais: os olhos, as orelhas, os pelos. Essas perguntas parecem percorrer caminhos não transitados por Hans e talvez indiquem caminhos para pensar na constituição do corpo pulsional da menina.

Decepcionada, Agathly perguntou: "E como Fritz entrou na mamãe? Quem o plantou no corpo dela? Quem plantou você na sua mãe? E Fritz, por onde saiu?". Jung devolveu a pergunta: "Por onde você acha que ele saiu?". Ela então mostrou os genitais, e ele confirmou. Agathly: "E como entrou na mamãe? Foi plantado em seu corpo, foi posta uma semente?". O pai explicou então que a mãe era como a terra e o pai, como o jardineiro. O pai colocava a semente na mãe, e ela crescia. Algumas semanas depois, ela teve um novo sonho: "Estava no jardim, e vários jardineiros se apoiavam nas árvores e faziam xixi"; entre eles, estava o papai. A questão da diferença sexual já estava posta, e pela primeira vez aparece o faz-xixi indicando o papel do pai na reprodução. Agathly continua interessada em como algo entra no corpo e como sai dele. O corpo é a sede das transformações, mas precisa ser regado, precisa de algo externo a ele, uma semente, um jardineiro, um pai, um faz-xixi.

Por aqueles dias, havia na casa um marceneiro aplainando uma gaveta emperrada, e ela sonhou que "o marceneiro estava aplainando os órgãos genitais dela". A pergunta agora era "o que o homem faz na mulher?" (JUNG, 1913/1964, p. 35). E, vale sublinhar, que ela está identificada com o lugar da mãe. Esboça-se assim a introdução de uma questão sobre o lugar do prazer no ato sexual. Nesses dias, o pai, que voltaria à cidade para trabalhar, perguntou a Agathly se queria ir com ele. Agathly: "Sim. Vou poder dormir com você?" (disse imitando um gesto da mãe). Pai: "Não, você vai dormir em outro quarto". Agathly estava com 5 anos e já tinha transitado um longo caminho de construção de um saber sobre a sexualidade (JUNG, 1913/1964, p. 36-37).

\section{Hilda e a falta de ATENÇÃo}

\footnotetext{
15 Vale lembrar que, na lenda da cegonha, ela pega as crianças do lago.

${ }^{16}$ Em carta de 18 de agosto de 1910.
} 
Em 1913, Abraham escreveu Pequena Hilda: fantasias e sintoma em uma menina de sete anos de idade, mas não o publicou. O texto tem a forma de um diário e só apareceu em 1974, na International Review of Psycho-Analysis, com notas de Dinora Pines, psicanalista da British Society, amiga de Hilda Abraham. Ficamos então sabendo que Hilda, assim como Agathly, a filha de Jung, foi uma das primeiras pacientes da psicanalise com crianças.

Mas antes disso, em 1909, ele fez a primeira menção a Freud sobre sua filha. Contou que foi preciso aplicar supositório de glicerina duas vezes em Hilda, que tinha dois anos e quatro meses, porque ela se recusava a fazer cocô. Surpreendeu-o que a menina o procurasse dizendo que "não queria outra injeção", sem mostrar afeto e com um leve sorriso. Ele concluiu, então, que Hilda desejava ser injetada, mas disse que não tinha observado outras manifestações de tendências de erotismo anal.

Abraham (1913/1959) aludiu a ela novamente numa breve menção, quando ela tinha três anos de idade. Disse que, por um período curto, Hilda sofreu de uma fobia de moscas e lagartas. Chamou atenção para as fobias de animais pequenos como moscas, vespas, borboletas e lagartas, que aparecem nas crianças e nos neuróticos. Nesse momento, ele se perguntou por que a fobia frequentemente toma por objeto animais pequenos, muitas vezes inofensivos, e considerou que isso se devia ao fato de eles aparecerem subitamente, roçarem o corpo inesperadamente e desaparecerem. Sustentou que o pequeno animal também representava o pai, mas destacou o fator surpresa. É o pai que entra de repente e surpreende a criança, advertindo-a com voz ameaçadora. A vantagem dos animais pequenos - e não grandes e de quatro patas - é que indicam o perigoso poder do pai, mas também permitem que a criança fantasie poder livrar-se dele, diz Abraham.

Ele volta a falar de Hilda quando ela tem quatro anos, dessa vez usando o nome de Helen (ABRAHAM, 1917/1955). Uma noite, enquanto jantava com ele, ela perguntou “Não é bom que mamãe não está em casa hoje?". O pai lhe perguntou por quê, e e ela disse: "Assim, não se intromete quando conversamos". Semanas mais tarde, ela expressou explicitamente seu desejo de morte ao perguntar à mãe: "Quando você vai morrer?". E, alguns dias depois, insistiu: "Daqui a dez anos, você ainda estará viva?". Abraham diz que as perguntas sempre se referiam à mãe e nunca ao pai. Certa vez, a mãe lhe respondeu: "Se eu morrer, você não terá uma mamãe!". E ela: "Mas eu ainda terei um papai". Outro dia, durante um jantar, também disse: “Papai, eu poderia vê-lo nu uma hora dessas?". Semanas mais tarde, fazendo compras com a mãe, lhe perguntava: "De qual chapéu você gosta mais? Que vestido você gostaria de ter?". Depois de a mãe apontar, ela dizia: "Quando eu for adulta, vou comprar isso para você". Abraham fala em formação reativa, mas assinala uma inversão da posição da menina, semelhante à solução edípica que podemos ler em Hans. Se a mãe vira filha, não precisa ser eliminada, e ela pode ficar com o pai. Até aí, tratam-se de pequenas alusões esparsas sobre Hilda, mas o tratamento psicanalítico só aconteceu quando ela estava com sete anos.

\section{O DIÁRIO}

O sintoma de Hilda naquele momento era a falta de atenção. Mesmo antes de entrar na escola, ao trocar de sapatos ou de roupa, parava no meio e ficava sentada, sem se mexer, e o mesmo foi apontado pela professora quando Hilda entrou na escola. Abraham complementou dizendo que Hilda era inteligente e que a desatenção desaparecia quando se interessava por algo, como uma história que Ihe contassem. Ela fazia perguntas e mostrava que era esperta. Também disse que ela havia confessado que se masturbava na cama e que um dia, ao perceber esse fato, o pai disse que isso lhe tiraria o sono.

Em função da queixa escolar, Abraham decidiu fazer uma tentativa de análise com a filha, seguindo o exemplo do relato do Pequeno Hans. Certo dia, saíram para andar, e ele the explicou que, como médico, realmente gostaria de saber o que estava havendo com ela, por que ela nunca prestava atenção na escola, sempre tinha sonhos diurnos em casa e ficava tanto tempo acordada quando se deitava, à noite. Ela disse que se esforçava para ter pensamentos agradáveis na escola, mas então vinham pensamentos feios e proibidos que se misturavam. Disse que tinha três fantasias recorrentes, mas, falando delas, só nomeou duas. A primeira era relativa a macacos: como se houvesse um alçapão no chão de seu quarto e, embaixo dele, houvesse macacos que lhe pudessem fazer alguma coisa. A segunda se referia a uma chama fogosa que poderia sair do chão. "Você está um pouco amedrontada?", perguntou Abraham. E a menina respondeu: "Amedrontada - não exatamente... Mas não sou tão valente quando penso naquela chama". De repente, ela se lembrou de que também pensava em gigantes... No entanto, ela sabia que eles só existiam nos contos de fadas. Então, apelando para sua autoridade de médico, o pai disse: "Frequentemente, ouço falar em sonhos de crianças em que um cachorro despertou ansiedade, mas o cachorro, na verdade, representava um 
humano". ${ }^{17}$ Ela imediatamente entendeu que, na verdade, estava com medo de homens, os quais, em suas fantasias, havia transformado em gigantes. Dois dias depois, ela deixou escapar a palavra "gigantes", que logo substituiu por "homens maus", e voltou ao assunto dos macacos e das chamas. Ela disse que um ladrão poderia entrar em casa e Ihe fazer alguma coisa: levá-la com ele para ver sua esposa, "querer ter uma criança" ou deixá-la morrer de fome. Se o ladrão a levasse embora, não seria possível voltar para casa novamente. Aí, falou do macaco que poderia devorála. Enquanto ia contando a história do ladrão, seu comportamento mudou de um jeito estranho, comentou Abraham. "Ela pegou meu braço, beijou a manga do meu casaco, enroscou a cabeça perto de mim e foi tão amorosa e terna, em palavras e olhares, que eu tive a impressão de que havia aspectos positivos em sua ansiedade a respeito do homem mordaz e assumi que eu mesmo devo ser um deles. Ela então quis falar da chama e disse que também poderia levá-la embora. Depois, veio me perguntar se eu já havia escutado de outras pessoas algo da mesma natureza e o que eu lhes havia oferecido. Eu disse que as pessoas se sentiam melhor quando falavam de seus pensamentos para o doutor, e, à noite, podiam se deitar em paz na cama. Depois disso, ela quis saber se eu era com meus pacientes da mesma forma que com ela e perguntou: "Eles te consultam com mais frequência, não é?".

Pouco tempo depois, assim como Hans, Hilda passou por uma amidalectomia e sofreu bastante com isso. Nesse momento, ela contou outra fantasia: "Um duende" - disse, indicando a altura de seu pequeno irmão - vem e a leva embora para os macacos. Os macacos podem mordê-la. Quando o pai lhe perguntou como, ela desenhou uma linha para baixo, no meio de seu corpo, do peito ao abdome. Lembrei-lhe de seus medos de que outros animais pudessem vir também, e ela imediatamente respondeu: "Um rato". O rato poderia pular da cabeceira para sua cama, rastejar por baixo dos lençóis e mordiscá-la. “Onde?”, perguntou Abraham. Novamente, fazendo o mesmo gesto, ela apontou o abdome e voltou ao assunto do homem mau que poderia vir e pegá-la. Um homem mordaz a faria morrer de fome ou a morderia, ou a levaria a um policial e contaria a ele que ela tinha feito algo mau, e assim ele a colocaria na prisão. Abraham então falou a Hilda sobre a autocensura das crianças e lhe explicou sua conexão com a masturbação, que ela voltou a confessar. Então, ela disse: "Bem, na verdade, eu me senti um pouco culpada a respeito disso". "Por quê?", perguntou Abraham. "Porque é mau", disse ela. Hilda Ihe explicou que, anteriormente, havia pensado nas fantasias com prazer, mas não o fazia mais. Perguntei se agora havia se tornado metade prazeroso e metade amedrontador, e ela respondeu: "Sim, é isso". Ela enfatizou que os pensamentos lhe ocorriam mesmo quando ela tentava pensar em outra coisa; eles vinham por si mesmos.

\section{AS CRIANÇAS TAMBÉM FALAM}

É interessante notar que, como esses casos são anteriores às mudanças técnicas introduzidas pela psicanálise com crianças, o tratamento ensaiado se fez de modo semelhante ao trabalho com adultos, ou seja, através de associação livre. Hilda compreendeu rapidamente o método, aceitou as interpretações do pai e as complementou. Ela estava com sete anos e já falava da divisão subjetiva e de sua experiência do inconsciente com uma clareza que muitos adultos não têm.

Embora menos invasivos que Max Graf, Jung e Abraham foram pais/analistas muito curiosos, o que fez com que seu lugar se aproximasse do de pesquisadores. Essa posição os enfraqueceu de algum modo como representantes da autoridade, o que teve consequências clínicas. A posição de pesquisador não é inócua. Por isso, é possível pensar que as fobias tenham surgido como anteparo ao desejo de saber dos pais. Na introdução de $O$ pequeno Hans, Freud fala da junção da autoridade médica e da conjunção do interesse terno com o científico. Mas, parafraseando Ferenczi, podemos perguntar: tratava-se da linguagem da ternura ou daquela da paixão?

Quando Hilda estava com sete anos, a fobia já havia passado, e ela estava em pleno processo de construção de uma pergunta que poderia ser situada do lado da histeria - interrogava-se sobre o desejo: “Os macacos, os ladrões, os gigantes, os ratos, o que querem de mim? O que querem de meu corpo que pulsa? Querem me morder, me deixar morrer de fome? Querem me roubar? Querem me fazer um filho?". Nesse momento da constituição subjetiva, no cerne de suas elaborações, não parece estar só o pai, mas o homem que a levará para longe dele. Se essa hipótese procede, a interpretação de Abraham não seria completamente correta. Se Hilda se agarra a ele e Ihe beija o braço, é porque sente culpa por fantasiar com outros além de seu pai. Algo semelhante aconteceu com Agatlhy e o marceneiro. Hermine teria razão em dizer que disso os pais não iam querer saber, preferindo as interpretações edípicas. O recalque já havia operado, daí a produção de ricas fantasias. $\mathrm{O}$ animais não estavam mais no espaço fóbico, mas a habitavam em seu corpo/psique. O supereu, por seu lado, tinha mudado experiências que outrora foram de prazer em desprazer e culpa. Não se tratava mais de medo, mas de estranheza e angústia frente a suas

${ }^{17}$ Provável alusão ao artigo Beiträege zur infantilen Sexualitätde (WULFF, 1912). 
fantasias e suas sensações corporais. Abraham, no entanto, não receita ritalina, mas assinala que falar disso pode ajudar.

\section{As teorias sexuais de Agathly e HiLda}

Ambas as meninas expressam com clareza fantasias sexuais em pleno processo de elaboração e também falam de erotismo e sedução; lembremos da chama ardente, de Hilda, e do marceneiro aplainando as gavetas, de Agathly. Assim, falam do quanto as ocupa querer saber sobre esse estranho gozo que sentem no corpo. O lugar do saber e da autoridade fica do lado paterno, enquanto com a mãe passa da identificação à rivalidade. Um traço do pai também aparece em destaque como voz do supereu. Trata-se de um rugido que faz o corpo tremer ou de um zumbido que penetra pelo ouvido ou pela pele. Não é uma figura unificada, mas um traço que enlaça temor e excitação; é o pai que cavalga entre o real e o imaginário.

A curiosidade aparece intimamente ligada à pulsão escópica: ver para saber. Enlaçando a pulsão epistemofílica, o olhar tem, nos dois casos, proeminência sobre outras pulsões. Ambas as meninas desejam ter um bebê, e a pulsão anal se enlaça ao papel ativo e produtivo - o filho é equivalente do cocô. A oralidade também tem um lugar de destaque: a boca está enlaçada a outros orifícios do corpo. Agathly coloca em série com ela o seio, por onde jorra o leite, e Hilda fala em passar fome como uma forma de castigo pelas suas fantasias de desejo proibido. As duas meninas parecem reconhecer o lugar da vagina, por onde nascem os bebês: a porta de saída dos animais da Arca de Noé, de Agathly, e o alçapão do piso do quarto, de Hilda. Ambas, desde muito cedo, se perguntam como é ser uma mulher (lembremos da ama e da mãe de Agathly) e qual é o prazer do ato sexual. Os objetos parciais e sua inserção no corpo são um enigma: como foram plantados os olhos, as orelhas, os cabelos? As pulsões que emergem com a força de um vulcão ou de uma chama ardente estilhaçam o corpo em pedaços.

As belas falas dessas meninas sonhadoras falam por si. Vale a pena escutá-las, depois de de terem ficado adormecidas tantos anos.

Recebido em: 4 de fevereiro de 2015. Aprovado em: 24 de julho de 2015.

\section{REFERÊNCIAS}

ABRAHAM, K. Restricciones y transformaciones de la escopofilia en los psiconeuróticos, con observaciones acerca de fenómenos análogos en la psicología de los pueblos (1913). In: Psicoanálisis clínico. Buenos Aires: Hormé, 1959, p. 128-177.

Some illustrations on the emotional relationship of little girls to the parentes (1917). In: . Clinical Papers and Essays on Psycho-analysis. 1955. Disponível em: <http://books.google.com.br/books? id $=$ XFNrLPjAty8C\&lpg=PA52\&ots=7-

P3h2cqFw\&dq=karl\%20Abraham\%201917\%20some\%20illustrations\%20on\%20the\%20emotional\%20relation ship\%20of\%20little\%20girls\%20to\%20the\%20parents\&hl=pt-BR\&pg=

PA53\#v=onepage\&q=karl\%20Abraham\%201917\%20some\%20illustrations\% 20on\%20the\%20emotional\%20relationship\%20of\%20little\%20girls\%20to\%20the\%20parents\&f=false> Acesso em: 2 dez. 2014

COSTA, A. Clinicando: escritas da clínica psicanalítica. Porto Alegre: APPOA, 2008.

FREUD, A. O tratamento psicanalítico de crianças (1926). Rio de Janeiro: Imago, 1971.

FREUD, S. Análisis de la fobia de um niño de cinco anos (1909). Buenos Aires: Amorrortu, 1996. (Obras completas, 10).

11).

Cinco conferencias sobre psicoanálisis (1909/1910). Buenos Aires: Amorrortu, 1996. (Obras completas,

Más allá del princpipio del placer (1920). Buenos Aires: Amorrortu, 1996. (Obras completas, 18).

Tótem y Tabú (1913). Buenos Aires: Amorrortu, 1996. (Obras completas, 13).

Tres ensayos de teoría sexual (1905). Buenos Aires: Amorrortu, 1996. (Obras completas, 7).

Un caso de paranoia que contradice la teoría psicoanalítica (1915). Buenos Aires: Amorrortu, 1996. (Obras completas,14).

Sigmund Freud e Carl Jung. Correspondencia. Madrid: Trotta, 2012.

; ABRAHAM, K. Correspondencia completa 1907-1926. Madrid: Síntesis, 2001.

GUELLER, A. S. Um nome proibido, uma história perdida. In: COLÓQUIO 100 ANOS DE PSICANÁLISE COM CRIANÇAS. Anais... São Paulo: Instituto Sedes Sapientiae, 2009. 
CROMBERG, R. U. Quando não se pode mais esquecer: C. G. Jung e Sabina Spielrein nos primórdios da psicanálise com crianças. Percurso, São Paulo, 2009, v. XXII, p. 17-36.

HUG-HELLMUTH, H. Essais psychanalytiques: destin et écrits d'une pionnière de la psychanalyse des enfants. Trad. Dominique Soubrenie. Paris: Payot, 1991.

JUNG, C. G. Análise da alma infantil. O desenvolvimento da personalidade (1910). Petrópolis: Vozes, 1983. (Obras completas, 12).

JUNG, C. G. Conflictos del alma infantil (1913). Buenos Aires: Paidós, 1964.

KLEIN, M. Psicoanálisis de niños (1921). Buenos Aires: Hormé, 1964.

The development of a child (1921). Buenos Aires: Hormé, 1964.

LACAN, J. El reverso del psicoanálisis (1969). Buenos Aires. Paidós, 1992. (Seminario XVII).

La angustia (1962-1963). Buenos Aires: Paidós, 2006. (Seminario X). La relación de objeto (1957). Buenos Aires: Paidós, 1994. (Seminario IV).

MELMAN, C. et al. A fobia. Rio de Janeiro: Revinter, 1994.

NUNBERG, H.; FEDERN, E. Las reuniones de los miércoles. Actas de la sociedad Psicoanalítica de Viena. Tomos I e II. Buenos Aires: Nueva Visión, 1979.

RIBEIRO DE CARVALHO, P. Édipo e castração, segundo o 'pequeno Hans'. In: O problema da identificação feminina primária. São Paulo: Escuta, 2000.

SAYERS, J. Mães da psicanálise: Helen Deutch, Karen Horney, Anna Freud, Melanie Klein. Rio de Janeiro: Jorge Zahar, 1992

WINNICOTT, D. W. El niño y el sexo (1947). In: El niño y el mundo externo. Buenos Aires: Hormé/Paidós, 1965. WULFF, M. Beiträege zur infantilen Sexualität. Zentralblatt für Psychoanalyse. 1912, v. 2, n. 1.

\section{Adela Stoppel de Gueller adela@gueller.com.br}

\section{Ana Costa}

medeirosdacostaanamaria@gmail.com

${ }^{1} \mathrm{O}$ artigo é resultado da pesquisa de pós-doutorado desenvolvida por Adela Stoppel de Gueller na UERJ, na área de Psicanálise, sob a supervisão da profa ${ }^{d} r^{a}$ Ana Costa e com financiamento da Capes. 